\title{
ANALISIS KINERJA BADAN KEPEGAWAIAN PENDIDIKAN DAN PELATIHAN DALAM PELAKSANAAN KENAIKAN PANGKAT PEGAWAI NEGERI SIPIL DI WILAYAH KABUPATEN MAHAKAM
} ULU

\author{
Oleh: \\ Nanik Pujiastuti ${ }^{1}$, Mulyanah ${ }^{2}$ \\ ${ }^{1}$ Fisipol, Fakultas Ilmu Sosial dan Ilmu Politik \\ Universitas 17 Agustus 1945 Samarinda, Indonesia \\ ${ }^{2}$ Fakultas Ilmu Sosial dan Ilmu Politik \\ Universitas 17 Agustus 1945 Samarinda 75234, Indonesia
}

\begin{abstract}
The promotion in the Mahakam Ulu District Government even though it has been implemented in the area still seems to use bureaucratic tortuous and policies that make it difficult for Civil Servants to be promoted. The problems in this research is how the implementation of promotion and inhibition factors promotion through the adjustment of diploma in the Government of Mahakam Ulu Regency. Research Objective to know the process of implementation of promotion of Civil Servant for those who get a diploma in Government of Mahakam Ulu Regency. In order to research for the development of theory and concepts as well as inputs to related institutions regarding the promotion of the rank of Civil Servant who btained a diploma. The approach used is normative through literature and empirical study through direct field research and also free guided interviews to the authorities related to research to complement the existing data. The increase of the rank of civil servant in Mahakam Ulu District Government has a role in its duty and function to conduct the process of appointment promotion through diploma for Civil Servant which is within the Government of Mahakam Ulu Regency, whose administrative process is done by Regional Personnel Board of Mahakam Ulu Regency
\end{abstract}

Keywords: : Performance of BKKP, Implementation of Promotion 


\section{ABSTRAK}

Kenaikan pangkat di Pemerintah Kabupaten Mahakam Ulu meskipun telah dilaksanakan di daerah masih terkesan menggunakan birokrasi yang berbelit-belit dan kebijakan-kebijakan yang mempersulit Pegawai Negeri Sipil yang akan naik pangkat. Permasalahan dalam penelitian ini adalah bagaimana pelaksanaan kenaikan pangkat dan faktor penghambat kenaikan pangkat melalui penyesuaian ijazah di Pemerintah Kabupaten Mahakam Ulu. Tujuan Penelitian untuk mengetahui proses pelaksanaan kenaikan pangkat Pegawai Negeri Sipil bagi yang memperoleh ijazah di Pemerintah Kabupaten Mahakam Ulu. Guna penelitian untuk pengembangan teori dan konsep serta masukan untuk instansi terkait berkenaan dengan kenaikan pangkat Pegawai Negeri Sipil yang memperoleh ijazah. Pendekatan yang digunakan besifat normative melalui studi kepustakaan dan empiris melalui penelitian langsung di lapangan dan juga wawancara bebas terpimpin kepada pihak-pihak yang berwenang yang berkaitan dengan penelitian untuk melengkapi data yang ada. Kenaikan Pangkat Pegawai Negeri Sipil di Pemerintah Kabupaten Mahakam Ulu memiliki peranan dalam tugas dan fungsinya untuk melakukan proses penyesuaian kenaikan pangkat melalui ijazah bagi Pegawai Negeri Sipil yang berada dalam lingkungan Pemerintah Kabupaten Mahakam Ulu, yang proses administrasinya dilakukan oleh Badan Kepegawaian Daerah Kabupaten Mahakam Ulu.

\section{Kata Kunci : Kinerja BKKP, Pelaksanaan Kenaikan Pangkat}

\section{PENDAHULUAN}

Badan Kepegawaian Negara merupakan lembaga yang menyelenggarakan manajemen Pegawai Negeri Sipil yang mencakup perencanaan, pengembangan sumber daya Pegawai Negeri Sipil dan administrasi kepegawaian, pengawasan dan pengendalian, penyelenggaraan dan pemeliharaan informasi kepegawaian, mendukung perumusan kebijaksanaan kesejahteraan Pegawai Negeri Sipil, serta memberikan bimbingan teknis kepada unit organisasi yang menangani kepegawaian pada instansi pemerintah pusat dan pemerintah daerah.

Kenaikan pangkat adalah penghargaan yang diberikan atas prestasi kerja dan pengabdian Pegawai Negeri Sipil terhadap negara, serta sebagai dorongan kepada Pegawai Negeri Sipil untuk lebih meningkatkan prestasi kerja dan pengabdiannya. Agar kenaikan pangkat dapat dirasakan sebagai penghargaan, maka kenaikan pangkat harus diberikan tepat pada waktunya 
dan tepat kepada orangnya. Adanya kenaikan pangkat ini dimaksudkan agar pegawai tersebut mampu meningkatkan tingkat produktivitasnya, memiliki motivasi yang lebih, untuk lebih melakukan hal-hal yang bersifat inovatif atau setidaknya tidak akan melanggar aturan yang ada dalam instansi.

Badan Kepegawaian Pendidikan dan Pelatihan Kabupaten Mahakam Ulu sebagai salah satu instansi pemerintah yang harus mengimbangi perubahan dan perkembangan tersebut agar dapat melaksanakan fungsinya sebagai instansi melayani masyarakat dengan baik. Salah satu caranya adalah dengan mengikuti Diklat yang dilaksanakan dalam lingkup Pemerintahan Kabupaten Mahakam Ulu. Diklat tersebut diberikan kepada Calon Pegawai Negeri Sipil (CPNS) dan Pegawai Negeri Sipil (PNS). Diklat yang diberikan kepada CPNS bertujuan agar dapat terampil dalam melaksanakan tugas yang dipercayakan padanya dan Diklat yang diberikan kepada PNS bertujuan untuk meningkatkan potensi yang dimiliki seperti mutu, keahlian, kemampuan, dan keterampilan pegawai. Sesuai dengan Undang-Undang Nomor 5 Tahun 2014, PNS wajib mengikuti Diklat sesuai dengan tupoksinya.

Menyadari pentingnya Diklat, diperlukan adanya koordinasi yang baik dari setiap bagian. Koordinasi penting dalam organisasi, karena didalamnya terdapat kegiatan yang berlainan dan dilakukan banyak orang, sehingga perlu adanya koordinasi yang baik agar tidak terjadi kesimpangsiuran kegiatan dan dapat ditujukan kepada titik arah pencapaian tujuan dengan efisien.

\section{KERANGKA DASAR TEORI}

Kinerja adalah segala hasil capaian dari segala bentuk tindakan dan kebijakan dalam rangkaian usaha kerja pada jangka waktu tertentu guna mencapai suatu tujuan.Definisi kinerja menurut Robbin dalam Nawawi (2006: 62), yakni kinerja adalah jawaban atas pertanyaan "apa hasil yang dicapai seseorang sesudah mengerjakan sesuatu."

Mangkunegara (2000: 67) mengatakan bahwa kinerja pegawai adalah hasil kerja secara kualitas dan kuantitas yang dicapai oleh seseorang pegawai dalam melaksanakan tugasnya sesuai dengan tanggungjawab yang diberikan kepadanya.Perhatian terhadap kinerja merupakan suatu hal yang perlu bagi sebuah organisasi ataupun perusahaan.

Pembinaan dan pengawasan manajemen pegawai negeri sipil di daerah dikoordinasikan pada tingkat nasional oleh Menteri dalam Negeri dan pada tingkat daerah oleh Gubernur. Standar, norma dan prosedur pembinaan dan pengawasan manajemen pegawai negeri sipil daerah diatur lebih lanjut oleh peraturan pemerintah. Pegawai negeri sipil merupakan individu yang 
mengabdikan dirinya kepada negara dan masyarakat. pegawai negeri sipil dituntut untuk menunjukansikap yang baik dan memberikan peranan yang optimal dalam pembangunan nasional. Untuk menjamin penyelenggaraan tugas pemerintah dan pembangunan nasional secara berdaya guna dan berhasil guna, diperlukan suatu sistem Pembinaan pegawai negeri sipil yang mampu memberikan keseimbangan terjaminnya hak dan kewajiban sebagai seorang pegawai negeri sipil.

Dalam peraturan pemerintah nomor 13 tahun 2002 tentang perubahan atas peraturan pemerintah nomor 100 tahun 2000 tentang pengangkatan pegawai negeri sipil dalam jabatan struktural pasal 7 yang berbunyi pegawai negeri sipil yang menduduki jabatan struktural harus mengikuti dan lulus pendidikan dan pelatihan sesuai dengan kopetensi yang telah ditetapkan untuk jabatan tersebut.

Kenaikan adalah penghargaan dan setiap penghargaan barulah mempunyai nilai apabila diberikan kepada orang yang tepat dan tepat pada waktunya, maka setiap atasan berkewajiban mempertimbangkan kenaikan pangkat bawahannya tepat pada waktunya. Pangkat adalah kedudukan yang menunjukkan tingkatan seseorang Pegawai Negeri Sipil berdasarkan jabatannya dalam rangkaian susunan kepegawaian dan digunakan sebagai dasar penggajian.

Menurut PP No. 99 Tahun 2000 \& PP No. 12 Tahun 2002, Kenaikan Pangkat adalah penghargaan yang diberikan atas prestasi kerja dan pengabdian Pegawai Negeri Sipil terhadap Negara, serta sebagai dorongan kepada Pegawai Negeri Sipil untuk lebih meningkatkan prestasi kerja dan pengabdiannya.

Kenaikan pangkat Pegawai Negeri Sipil ditetapkan pada tanggal 1 April dan 1 Oktober tiap tahun, kecuali untuk beberapa jenis kenaikan pangkat yang ditetapkan berlakunya secara khusus.

Ditegaskan dalam Undang-undang No. 8 Th. 1974 pasal 18 ayat (2) beserta penjelasannya, bahwa kenaikan pangkat reguler adalah merupakan hak. Oleh sebab itu apabila seorang Pegawai Negeri Sipil memenuhi syaratsyarat yang ditentukan, pada dasarnya harus dinaikan pangkatnya kecuali apabila ada alasan yang syah untuk menundanya.

Ditegaskan pula dalam pasal 7 peraturan Pemerintah No. 3 Th. 1980 bahwa kenaikan pangkat regular adalah kenaikan pangkat yang diberikan kepada Pegawai Negeri Sipil yang memenuhi syarat-syarat yang ditentukan tanpa memperhatikan jabatannya yang dipangkunya. 


\section{METODE PENELITIAN}

\section{A. Jenis Penelitian}

Penelitian ini berfokus pada penelitian bersifat deskriptif kualitatif yang bertujuan menggambarkan secara tepat bidang-bidang pekerjaan, keadaan, gejala atau kelompok jabatan, atau untuk menentukan ada tidaknya hubungan pengaruh dan sebab akibat terhadap peningkatan kinerja pegawai.

\section{B. Fokus Penelitian}

Lokasi penelitian dilakukan pada Badan Kepegawaian Pendidikan dan Pelatihan Kabupaten Mahakam Ulu

\section{Tekhnik Pengumpulan Data}

1. Data Primer

Penulis melakukan observasi pengamatan secara langsung (tanpa alat) terhadap gejala diteliti. Penulis melakukan observasi dengan metode partisipan, artinya penulis tidak mengambil jarak dengan penelitian yang diselidiki yakni merupakan bagian dari subyek yang diteliti. Hal ini penulis lakukan dengan pertimbangan agar informasi atau data yang diperoleh lebih valid adanya karena penulis bekerja pada Badan Kepegawaian Pendidikan dan Pelatihan Kabupaten Mahakam Ulu.

2. Data Sekunder

Data sekunder diperoleh dari Badan Pendidikan dan Pelatihan Kabupaten Mahakam Ulu.dan juga diperoleh melalui media elektronik (internet), buku panduan program kegiatan Diklat Mahakam Ulu., dan data lainnya yang mendukung penelitian.

\section{Tekhnik Analisa Data}

Analisa data dilakukan berdasarkan data yang diperoleh dari Badan Kepegawaian Pendidikan dan Pelatihan Kabupaten Mahakam Ulu., dan pengamatan secara langsung mengenai pendidikan dan pelatihan. Analisa data juga didukung dari teori buku dengan melakukan perbandingan dengan praktek dilapangan dengan harapan dapat melihat kondisi ideal.

\section{HASIL DAN PEMBAHASAN}

\section{A. Gambaran Umum Lokasi}

Badan Kepegawaian Pendidikan dan Pelatihan Kabupaten Mahakam Ulu terbentuk berdasarkan Peraturan Bupati Mahakam Ulu Nomor 27 Tahun 2016 tentang Susunan Organisasi dan Tata Kerja Perangkat Daerah; Badan Kepegawaian Pendidikan dan Pelatihan mempunyai tugas membantu Bupati 
dalam melaksanakan fungsi penunjang Urusan Pemerintahan dibidang Kepegawaian, Pendidikan dan Pelatihan.

Visi merupakan pandangan jauh ke depan, kemana dan bagaimana Kabupaten Mahakam Ulu harus dibawa dan berkarya agar konsisten dan dapat eksis, antisipatif, inovatif serta produktif. Dengan bertitik tolak dari fakta sejarah, potensi dan kondisi factual yang digali dari nilai-nilai luhir yang dianut oleh seluruh komponen stakeholder yang ada di Kabupaten Mahakam Ulu maka pernyataan Visi untuk membangun Kabupaten Mahakam Ulu "MEMBANGUN MAHULU UNTUK SEMUA : SEJAHTERA BERKEADILAN"

Rumusan visi diatas merupakan rumusan prioritas pembangunan di Kabupaten Mahakam Ulu yang menjadi fokus dan arahan pembangunan serta program kerja selama lima tahun kedepan.

Sedangkan Misi merupakan rumusan umum mengenai upaya-upayaupaya yang akan dilaksanakan untuk mewujudkan visi yang telah ditetapkan. Untuk mencapai visi yang telah diuraikan diatas, Pemerintah Kabupaten Mahakam Ulu menetapkan misi pembangunan adalah sebagai berikut :

1. Membangun dan meningkatkan sarana dan prasarana publik yang berkualitas, adil, berkelanjutan dan berwawasan lingkungan;

2. Meningkatkan taraf hidup masyarakat dengan memanfaatkan potensi sumber daya alam, memberdayakan usaha ekonomi kecil menengah yang berbasis kerakyatan, dan perluasan lapangan kerja termasuk pengembangan ekonomi kreatif berbasis pariwisata dan kearifan lokal;

3. Mewujudkan masyarakat yang cerdas, sehat, sejahtera, bermartabat dan berdayasaing tinggi;

4. Menciptakan tata pemerintahan yang bersih, berwibawa, transaparan dan akuntabel.

\section{B. Hasil Penelitian}

1. Analisis Penyesuaian Ijazah Sebagai Sarana Kenaikan Pangkat

\section{a. Prosedur Pelaksanaan Penyesuaian Ijazah}

Badan Kepegawaian Pendidikan dan Pelatihan Kabupaten Mahakam Ulu kemudian membuat prosedur sendiri dengan beberapa tambahan persyaratan administrative dan prosedur tekhnis untuk dilalui pegawainya yang ingin mendapatkan penyesuaian ijazah. Prosedur itu dikeluarkan setelah melalui rapat yang diikuti semua pejabat eselon satu dan eselon dua serta kepala bagian pengembangan pegawai selalu memimpin bagian yang melaksanakan kegiatan ujian penyesuaian ijazah pada Badan Kepegawaian Pendidikan dan Pelatihan Kabupaten Mahakam Ulu. Hal ini merupakan pernyataan dari Kepala Bidang Data kepangkatan kesejahteraan pensiun ASN sebagai informan, yaitu : 
Jadi untuk mengatur prosedur pelaksanaan, semua eselon satu dan eselon dua serta saya sebagai bagian yang melaksanakan penyesuaian ini berkumpul untuk merapatkan bagaimana prosedur itu. Tentu prosedur itu tidak asal dibuat. Kami dibantu oleh konsultan dari kalangan professional untuk membuat prosedur ini. Prosedur ini kemudian dituangkan lewat Surat Keputusan Menteri Hukum dan HAM. (Wawancara, 27 April 2018)

Pelaksanaan kegiatan penyesuaian ijazah ini, setiap tahunnya Badan Kepegawaian Pendidikan dan Pelatihan Kabupaten Mahakam Ulu membentuk Panitia Ujian Penyesuaian Ijazah Sarjana (S1) dan Magister (S2) yang mempunyai tugas melaksanakan seleksi administrative bagi para pegawai negeri pada Badan Kepegawaian Pendidikan dan Pelatihan Kabupaten Mahakam Ulu yang ingin mendapatkan penyesuaian ijazah. Hal ini ditetapkan oleh Surat Keputusan Menteri Hukum dan Hak Asasi Manusia Republik Indoonesia. Bagian Pengembangan pegawai biro kepegawaian adalah bagian yang bertanggung jawab dengan pelaksanaan penyesuaian ijazah ini pada Badan Kepegawaian Pendidikan dan Pelatihan Kabupaten Mahakam Ulu dan juga di tingkat nasional.

Pelaksanaan kegiatan penyesuaian ijazah, prosedur penyesuaian ijazah yang harus dilalui oleh seorang pegawai negeri yang ingin mendapatkan kenaikan pangkat pilihan ini ada dua prosedur. Prosedur ini sendiri diatur dalam Surat Keputusan Menteri Hukum dan Hak Asasi Manusia Republik Indonesia. Pegawai negeri pada Badan Kepegawaian Pendidikan dan Pelatihan Kabupaten Mahakam Ulu yang ingin mendapatkan penyesuaian ijazah harus melewati prosedur administrative dan prosedur tekhnis. Hal ini sesuai dengan hasil wawancara dengan panitia pelaksanaan penyesuaian ijazah pada Badan Kepegawaian Pendidikan dan Pelatihan Kabupaten Mahakam Ulu:

Secara garis besar sih peserta harus melewatu syarat administratif dan teknis. Kalau administratif ya harus menyerahkan dokumen kelengkapan peserta supaya bisa mendapat kenaikan pangkat ini. Nah kalau teknisnya ya ikut ujian, ngumpulin karya tulis terus udah tinggal nunggu hasil deh lulus apa coba lagi tahun depan. (Wawancara dengan paniitia pelaksaaan ujian penyesuaian ijazah, 27 Januari 2018)

Prosedur administratif adalah syarat-syarat kelengkapan yang harus dipenuhi pegawai yang ingin mendapatkan penyesuaian ijazah. Syarat-syarat administrative berupa surat-surat yang mendukung pengawai untuk bisa mendapatkan penyesuaian ijazah. Sedangkan prosedur teknis adalah tahapan-tahapan yang harus dijalankan 
pegawai negeri yang ingin mendapatkan penesuaian ijazah. Prosedur teknis yang harus dijalankan untuk mendapatkan penyesuaian ijazah mengikuti ujian tertulis yang diadakan serentak diseluruh Indonesia dan dinatakan lulus dalam ujian penyesuaian ijazah tersebut serta mengerjakan karya tulis yang temanya berhubungan dengan pekerjaan yang pegawai negeri tersebut jalani. Setelah semua prosedur ini dilaksanakan oleh pegawai negeri barulah berhak untuk mendapatkan kenaikan pangkat pilihan ini.

\section{1) Prosedur Administratif}

Persyaratan administratif yang harus pegawai negeri kumpulkan dalam mengambil penyesuaian ijazah :

a. Foto Copy ijazah yang telah dilegalisir oleh pejabat yang berwenang

b. Surat Keputusan Kenaikan Pangkat terakhir

c. Pas photo berwarna dengan berlatar belakang merah ukuran $3 \times 4$ sebanyak 3 lembar

d. Karya Tulis dengan judul sesuai bidang pekerjaan masing-masing dan diketik 2 spasi dikertas kuarto dengan batas minimal 10 hal bagi sarjana (S1) dan minimal 20 hal bagi magister (S2)

e. Foto Copy DP3 dua tahun terakhir

f. Surat ijin belajar dari pimpinan

Bahan tersebut di masukan kedalam map Snelhelter

- Golongan II Warna Kuning

- Golongan III Warna Merah

\section{2) Prosedur Tekhnis}

Persyaratan teknis dalam penyesuaian ijazah yang diatur pada Badan Kepegawaian Pendidikan dan Pelatihan Kabupaten Mahakam Ulu secara umum peserta harus:

a. Memiliki ijazah yang relevan antara bidang tugas dengan ijazah dari program bidang studi

b. Telah 2 (dua) tahun menjadi pegawai negeri

c. Mengikuti pelaksanaan Ujian Penyesuaian Ijazah

d. Mengerjakan Karya Tulis yang berhubungan dngan bidang pekerjaan

Pegawai negeri pada Badan Kepegawaian Pendidikan dan Pelatihan Kabupaten Mahakam Ulu yang telah dua tahun menjadi pegawai negeri baru dapat mengikuti penyesuaian ijazah karena setelah dia resmi mendapat SK penerimaannya. Kemudian teknis disini adalah jelas peserta harus mengikuti pelaksanaan ujian 
penyesuaian ijazah dan mengerjakan karya tulis yang berkaitan dengan pekerjaannya.

Pelaksanaan ujian penyesuaian ijazah sendiri seperti layaknya ujian-ujian pada umumnya. Pada peserta ujian yang merupakan pegawai negeri dari Badan Kepegawaian Pendidikan dan Pelatihan Kabupaten Mahakam Ulu melaksanakan ujian di Pusat Pendidikan dan Latihan. Para Pengawas ujiannya sendiri adalah para panitia pelaksanaan penyesuaian ijazah.

Pelaksanaan penyesuaian ijazah ini sebenarnya diadakan sebagai salah satu upaya untuk memacu para pegawai negeri di Indonesia secara umum dan khusunya dalam lingkungan Kabupaten untuk lebih terpacu dalam meningkatkan kemampuan dengan mendapatkan pendidikan yang lebih tinggi. Hal ini baik maksudnya karena seorang pegawai negeri yang tidak memiliki pendidikan formal yang tinggi dan hanya mengandalkan kenaikan angkat regular maka susah mencapai pangkat yang tinggi dan berakibat mengecilnya kemungkinan untuk menduduki suatu jabatan structural menjadi lebih kecil.

\section{3) Pelaksanaan Penyesuaian Ijazah}

Kelebihan yang dimiliki oleh pekerjaan sebagai pegawai negeri yakni jenjang kepangkatan yang jelas dan banyaknya jenis kenaikan pangkat yang dapat diambil oleh pegawai negeri dalam karir kepegawaiannya. Adanya kenaikan pangkat regular merupakan hal yang menguntungkan bagi pegawai negeri karena selalu diberikan secara rutin setiap empat tahun sekali.

Penyesuaian ijazah sebagai salah satu kenaikan pangkat pilihan merupakan salah satu keadilan dalam system pangkat yang ada di Indonesia. Keadilan yang dimaksud adalah seorang pegawai negeri yang telah bersusah ayah menempuh pendidikan yang lebih tinggi dalam rangka meningkatkan kemampuannya sebagai upaya untuk lebih baik lagi, sehingga pada akhirnya membantu kinerja organisasi pemerintahan tempat pegawai negeri tersebut bekerja berkaitan dengan kegiatannya sebagai pelayanan terhadap masyarakat. Pegawai negeri tersebut memperoleh ijazah baru dari pendidian yang diambil, kemudian berhak mendapatkan penghargaan atas usahanya tersebut. Penghargaan yang pantas diberikan adalah kenaikan pangkat yang menjadikan pangkat pegawai negeri itu sesuai dengan kemampuan yang dimilikinya. Hal ini seperti dikatakan informan yang bernama Heribertus sebagai panitia dalam hal wawancara : 
Penyesuaian ijazah ini kan merupakan acuan agak pegawai meningkatkan kemampuan mereka. Memang kalau dilihat dari masa kerja sepintas ini tidak adil tetapi semua kan berhak mendapatkan penyesuaian ijazah. Ini berarti adilkan jika orang yang lebih ingin berkembang diberikan penghargaan yang lebih. (Wawancara dengan panitia pelaksanaan ujian penyesuaian ijazah, 27 Januari 2018)

Jenis kenaikan pangkat melalui penyesuaian ijazah ini mempunyai keunikan tersendiri yakni merupakan satu-satunya dari jenis kenaikan pangkat yang dapat menaikan pangkat seorang pegawai negeri lebih dari satu tingkatan pangkat dalam satu kali kenaikan pangkat (dalam kasus ini seorang pegawai negeri yang berpangkat II/a dan kemudian memperoleh ijazah S1 maka setelah lulus uian penyesuaian ijazah dapat langsung berpangkat III/).

Hal ini memang terkesan tidak adil karena untuk mengalami kenaikan pangkat secara regular dari II/a ke III/a pada normalnya memakan waktu kurang lebih 16 tahun dari masa kerja pegawai. Pegawai negeri yang ingin karirnya cepat naik sering kali mencoba berkuliah demi mendapatkan ijazah saja bukan untuk meningkatkan kemampuannya demi mengikuti ujian penyesuaian ijazah. Hal tersebut dikarenakan dibandingkan waktu kuliah yang rata-rata hanya 4 tahun maka percepatan kenaikan pangkat yang akan didapat seorang pegawai negeri sangatlah jauh perbedaan waktunya. Contohnya pegawai negeri yang masuk memakai ijazah SMA pada saat penerimaan pegawai dan pegawai itu berhak mendapatkan pangkat II/a kemudian mendapatkan ijazah S1 maka sesuai dengan peraturan sebenarnya pangkat terendah yang harusnya dimiliki oleh seorang pegawai negeri yang memiliki ijazah S1 adalah pangkat III/a. sehingga pegawai negeri tersebut dapat langsung mendapatkan pangkat III/a-nya tanpa harus melalui pangkat-pangkat diantara. Padahal jika hanya menggunakan ijazah SMA saja maka pegawai negeri tidak akan mungkin untuk mencapai pangkat III/a karena pegawai negeri dengan ijazah SMA hanya berhak memiliki pangkat sampai dengan II/d saja.

Penulis melihat hal ini sebagai suatu keanehan karena pelaksanaan penyesuaian ijazah adalah salah satu cara penghargaan terhadap ijazah yang pegawainya peroleh melalui peningkatan pendidikan tetapi pada penerimaan kurang menghargai calon pegawai yang memiliki ijazah S1. Namun hal ini di sebabkan oleh formasi kepegawaian yang menjadikan hal ini seperti ini terjadi. Seperti kutipan wawancara dengan Kepala Sub bidang pengadaan pengadaan dan mutasi yang bernama Nancy Mayang Sari sebagai berikut : 
Ini arahnya sebenarnya ke formasi pegawai. Kalau pada penerimaan lowongan yang dibuka pastinya hanya ijazah SMA dan ijazah S1 yang memiliki hubungan dengan pekerjaan departemen ini. Paling hanya sarjana hukum, sarjana komunikasi, dan sarjana administrasi kayak kamu lah. Jadi kalau ada orang yang punya sarjana kehutanan ya susah diterima disini tidak ada lowongan dalam formasi penerimaan. Satu-satunya jalan kalau mau jadi pegawai sini lewat ijazah SMA-nya. (Wawancara dengan panitia pelaksanaan uian penyesuaian ijazah, 27 Januari 2018)

Ada motivasi juga yang membuat seorang pegawai negeri mengikuti penyesuaian ijazah, yakni ingin mendapat paangkat yang lebih tinggi agar mendapatkan gaji yang lebih besar dan juga motivasi untuk aktualisasi diri agar lebih terpandang dalam lingkungan pekerjaan. Seperti yang dikatakan salah seorang peserta dalam wawancara :

Ya paling naik gaji, itu kan hubungan juga sama naik pangkat terus. Lalu kalau sudah S1 kan enak tuh lebih dipandang. Ga ada lagi kerjaan ngelap gallon, foto copy. Pokoknya lebih dipandang lah. (Wawancara dengan peserta ujian penyesuaian ijazah, 27 Januari 2018)

Pelaksanaan penyesuaian ijazah pada tahun 2016 dan 2017 secara administratif masih terjadi penyimpangan dari prosedur, banyak kendala yang dihadapi seperti masalah belum dianggap pentingnya persyaratan administratif ini. Sehingga banyak pegawai yang mempunyai ijazah baru, mengikuti penyesuaian ijazah dengan persyaratan administratif yang tidak lengkap seperti tidak pernah mengurus surat ijin belajar atau hanya memperlihatkan ijazah asli karena merasa lebih mudah daripada mengurus kembali legalisir ijazah di kampusnya, padahal foto copy itu merupakan arsip yang harus disimpan sebagai data yang akan dipertanggungjawabkan.

Masalah ini muncul karena kedekatan panitia dengan peserta yang merupakan sama-sama pegawai negeri di Setken Depkumham. Perasaan ini yang kadang mendorong panitia tidak tegas dalam menindak calon peserta yang tidak melengkapi persyaratan. Ini diperkuat dengan pernyataan dari wawancara dengan panitia penyesuaian ijazah :

Kendala yang paling besar itu rasa ga enak sama teman sendiri. Jadi kadang suka lewatin aja deh. Abis diminta syarat-syaratnya susah. Namanya aja kerja ya ada yang sibuklah ada yang males ngurus lah. (Wawancara dengan panitia pelaksanaan penyesuaian ijazah, 27 Januari 2018) 
Kendala teknis yang ada di tahun 2016 dan 2017 kurang lebih sama yakni kekurangan tenaga panitia. Jika melihat jumalah peserta dari Setjen saja memang tidak terlalu banyak tetapi jika melihat dari jumlah keseluruhan seluruh Indonesia susah untuk memeriksa karya tulis karena semua karya tulis dikirimkan ke bagian pengembangan pegawai.

\section{Pembahasan}

1. Mengatasi Hambatan Dalam Kenaikan Pangkat Pegawai

Hambatan Kultural berkaitan dengan Budaya Kerja. Budaya kerja guru pada dasarnya merupakan nilai-nilai yang menjadi kebiasaan seorang guru yang menentukan kualitas kerja.Hambatan ini dapat diartikan sebagai hambatan budaya kerja pegawai yang tidak mendukung perbaikan karir pegawai.

Hambatan Administratif yaitu :

- Kelemahan mengarsipkan surat, SK, surat tugas atau bukti fisik lainnya

- Kelemahan menyajikan bukti-bukti untuk kenaikan pangkat

- Kelemahan dalam pemahaman peraturan tentang jabatan guru

- Ketidaktepatan waktu pengusulan berkas kenaikan pangkat

Hambatan Struktural yaitu :

a. Keterlambatan dalam pengajuan kenaikan pangkat

b. Pegawai sering terjebak pada rutinitas, sehingga usul kenaikan pangkatnya kadang terlambat disampaikan atau karena persyaratan yang tidak kunjung lengkap. Ini harus diantisipasi oleh para pegawai.

Keterbatasan tenaga Tim Penilai Angka Kredit pegawai baik ditingkatan Kabupaten maupun tingkat Provinsi untuk mengatasi hambatan hambatan tersebut ada beberapa langkah yang harus ditempuh pegawai sehingga proses kenaikan pangkat dan jabatan pegawai dapat berjalan lancar tanpa hambatan yang berarti, tentunya juga guna mendukung karir pegawai itu sendiri.

Pegawai merupakan sebuah profesi. Didalamnya banyak peraturan yang menaungi pegawai dalam rangka mengembangkan profesi tersebut. Sudah selayaknya bagi setiap pegawai senantiasa memahami peraturan yang ada guna mewujudkan pegawai yang professional. Peraturan peraturan yang ada banyak dimuat dalam sebuah buku, jurnal, surat edaran, majalah, internet dan lain-lain tinggal peran aktif dari pegawai yang bersangkutan untuk mengaksesnya.

Pemenuhan syarat administratif ini juga berkaitan dengan poin 2 di atas yakni pegawai harus paham terhadap peraturan yang ada khususnya peraturan tentang jabatan fungsional pegawai serta peraturan yang lainnya berkaitan dengan peningkatan karir profesi seorang pegawai. 


\section{PENUTUP}

1. Asas-Asas Promosi Jabatan, dimana pelaksanaan asas- asas ini pada umumnya sudah berjalan berjalan dengan baik hal ini bisa dilihat sebagian bahwa sebagian responden merasa jabatannya telah sesuai dengan latar belakang pendidikannya walaupun sebenarnya masih ada sebagian yang merasa kurang sesuai dan bahkan tidak sesuai dengan latar belakang pendidikannya. Hal ini penting bahwa dalam teori manajemen sumberdaya manusia bahwa segala bentuk tugas atau pekerjaan haruslah diserahkan pada yang ahli dibidangnya disamping itu juga berkaitas engan jabatan yang lowong belum sepenuhnya Badan Kepegawaian Daerah Kabupaten Mahakam Ulu menempatkan orang sesuai dengan apabila terjadi kekosongan jabatan sehingga pelaksanaan promosi jabatan masih adanya pengakuan dari beberapa pegawai bahwa pelaksanaan promosi jabatan selama ini tingkat objektifitasnya belum optimal dalam arti masih kental adanya suasana kesukuan, hubungan kedekatan dan lain sebagainya.

2. Prosedur Promosi jabatan, secara umum dapat disimpulkan berjalan cukup baik. Dimana dapat dilihat bahwa transparansi prosedur, dan juga waktu pelaksanaa promosi jabatan cukup diketahui oleh pegawai, meskipun terkadang juga tidak diketahui oleh sebagian pegawai hal ini juga disebabkan kurangnya sosialisasi yang dilakukan Badan Kepegawaian Daerah atau pemberitahuan secara resmi sehingga kenyataan yang ada, promosi jabatan tersebut terjadi secara tiba- tiba hal ini tentu tidak sehat dalam pelaksanaan promosi jabatan yang pada akhirnya tingkat efektifitas dan efisiensi pelaksanaan promosi jabatan belum sepenunhya optimal.

\section{DAFTAR PUSTAKA}

Pemerintah Nomor 99 Tahun 2000 tentang Kenaikan Pangkat Pegawai Negeri Sipil sebagaimana telah diubah dengan Peraturan Pemerintah Nomor 12 Tahun 2002

Peraturan Pemerintah Nomor 3 Tahun 1980 Tentang Pengangkatan Dalam Pangkat Pegawai Negeri Sipil

Mangkunegara, Anwar Prabu. 2006. Evaluasi Kinerja Sumber Daya Manusia. Bandung : Refika Aditama hal 9

Mangkunegara, Anwar Prabu. 2006. Evaluasi Kinerja Sumber Daya Manusia. Bandung : Refika Aditama hal 67 


\section{INTERNET}

http://humas.kutaitimurkab.go.id/index.php/home/detail/1285/diklat-pim-ivadopsi-pola-baru-diharapkan-membentuk-pemimpin-perubahan

http://bandiklat.kaltimprov.go.id/read/news/2015/766/kepala-badan-diklatkutim--akreditasi-lembaga-diklat-harus-memenuhi-standar-lan.html 